\title{
Syndromic diarrhea/Tricho-hepato-enteric syndrome
}

\author{
Alexandre Fabre ${ }^{1,2}$, Christine Martinez-Vinson ${ }^{3}$, Olivier Goulet ${ }^{4}$ and Catherine Badens ${ }^{1,5^{*}}$
}

\begin{abstract}
Syndromic diarrhea/Tricho-hepato-enteric syndrome (SD/THE) is a rare and severe bowel disorder caused by mutation in SKIV2L or in TTC37, 2 genes encoding subunits of the putative human SKI complex. The estimated prevalence is $1 / 1,000,000$ births and the transmission is autosomal recessive. The classical form is characterized by 5 clinical signs: intractable diarrhea of infancy beginning in the first month of life, usually leading to failure to thrive and requiring parenteral nutrition; facial dysmorphism characterised by prominent forehead and cheeks, broad nasal root and hypertelorism; hair abnormalities described as woolly and easily removable; immune disorders resulting from defective antibody production; intrauterine growth restriction. The aetiology is a defect in TTC37, a TPR containing protein, or in the RNA helicase SKIV2L, both constituting the putative human ski complex. The ski complex is a heterotetrameric cofactor of the cytoplasmic RNA exosome which ensures aberrants mRNAs decay. The diagnosis SD/THE is initially based on clinical findings and confirmed by direct sequencing of TTC37 and SKIV2L. Differential diagnosis with the other causes of intractable diarrhea is easily performed by pathologic investigations. During their clinical course, most of the children require parenteral nutrition and often immunoglobulin supplementation. With time, some of them can be weaned off parenteral nutrition and immunoglobulin supplementation. The prognosis depends on the management and is largely related to the occurrence of parenteral nutrition complications or infections. Even with optimal management, most of the children seem to experience failure to thrive and final short stature. Mild mental retardation is observed in half of the cases.
\end{abstract}

\begin{abstract}
French
Les diarrhées syndromiques ou syndrome tricho-hepato-enterique (SD/THE) sont un syndrome rare et sévère dont I'incidence est estimée à 1 cas pour 1 million de naissances et la transmission autosomique récessive. La forme typique associe 5 signes cliniques: une diarrhée grave rebelle nécessitant dans la majorité des cas une nutrition parentérale du fait de la malnutrition, une dysmorphie avec un front large et bombé, une racine du nez large et un hypertélorisme, des anomalies des cheveux qui sont fragiles, cassants, incoiffables et qualifiés de "laineux », un retard de croissance intra utérine et des anomalies de l'immunité à type de déficit en immunoglobuline ou d'absence de réponse aux antigènes vaccinaux. Des anomalies de deux protéines peuvent être à l'origine du syndrome SD/THE: TTC37, une protéine à motif TPR et SKIV2L, une hélicase à ARN, toutes 2 étant des constituants du complexe SKI humain. Le complexe SKI est un co-facteur de l'exosome cytoplasmique qui assure la dégradation des ARN aberrants ou exogènes. Le diagnostic est d'abord clinique puis confirmé par le séquençage des gènes (Continued on next page)
\end{abstract}

\footnotetext{
* Correspondence: Catherine.badens@ap-hm.fr

1UMR_S 910, Inserm-Faculté de Médecine, Aix-Marseille Université, 13385,

Marseille, France

${ }^{5}$ AP-HM, Laboratoire de Génétique Moléculaire, Hôpital d'Enfants de la

Timone, 13385, Marseille, France

Full list of author information is available at the end of the article
}

\section{Biomed Central}

(c) 2013 Fabre et al.; licensee BioMed Central Ltd. This is an Open Access article distributed under the terms of the Creative Commons Attribution License (http://creativecommons.org/licenses/by/2.0), which permits unrestricted use, distribution, and reproduction in any medium, provided the original work is properly cited. 


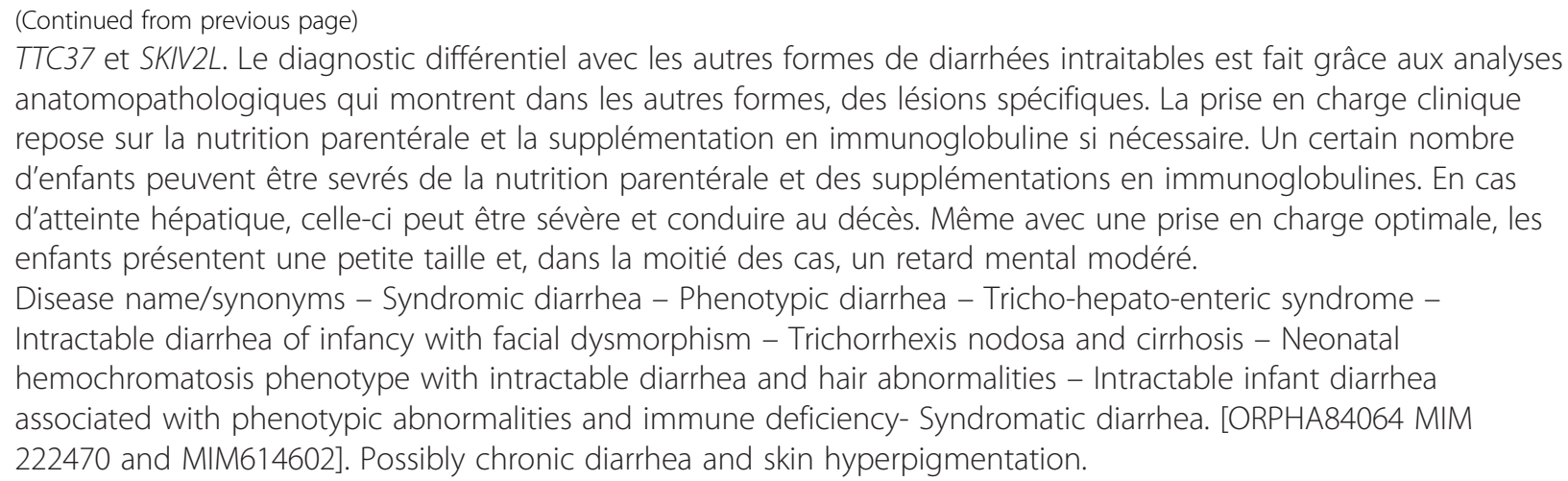

Keywords: SKI COMPLEX, SKIV2L, TTC37, WDR61, SKI3, SKI2, SKI8, Intractable diarrhea, Syndromic diarrhea, Trichohepato-enteric syndrome, Woolly hair

\section{Definition}

The classical form of Syndromic Diarrhea/Tricho-hepatoenteric syndrome (SD/THE) associates an intractable diarrhea of infancy with facial dysmorphism, abnormal hair and immune deficiency; intra uterine growth restriction (IUGR) or small for gestational age (SGA) is often present [1]. SD/THE is a disease genetically heterogeneous, phenotypically homogeneous, caused by mutations in TTC37 (HGNC:23639) or in SKIV2L (HGNC:10898), 2 genes encoding co-factors of the putative human SKI complex [2-4]. $\mathrm{SD} / \mathrm{THE}$ is classified in the group of congenital diarrheal disorders which consists of 4 categories depending on i) the alteration in absorption and transport of nutrients and electrolytes, ii) enteroendocrine cell differentiation, iii) modulation of the intestinal immune response and iv) enterocyte differentiation and polarization [5]. SD/THE is part of the enterocyte alteration diseases which includes also tufting enteropathy and microvillus atrophy disease [5].

\section{Historical note}

First described by Stankler et al. in 1982 [6] and further delineated by Girault et al. in 1994 [7], the definition of the syndrome has been complicated by the description of the tricho-hepato-enteric syndrome as probably distinctive in 1997 [8]. New cases were reported between 2000 and 2007 [9-12] using alternatively one or the other denominations. In 2007, we proposed to group the two syndromes under the same entity [1]. This suggestion was proven relevant with the imputation of TTC37 [2,3] as causative of $2 / 3$ of $\mathrm{SD} / \mathrm{THE}$ cases, without clear clinical delineation. More recently, the identification of $S K I V 2 L$ mutations as causing the missing third of $\mathrm{SD} / \mathrm{THE}$ permitted us to confirm the unity of the syndrome [4].

\section{Epidemiology}

SD/THE is a rare disease. Between 1982 and 2012, 44 cases have been published [2-15]. During the last 20 years, 13 cases have been diagnosed in children born in France [3,4 and personal data] which, according to the annual number of births in France, indicates a prevalence of at least $1 / 1,000,000$. It should be noted that 21 cases out of 44 are from consanguineous families. The prevalence may be underestimated due to the fact that only patients with important gastrointestinal manifestations are referred to specialists. SD/THE seems to be present in all populations. To date, patients have been described in Indian, European and Mediterranean populations (from the UK, Italy, France, Poland, Turkey and North Africa).

\section{Clinical description}

From the review of the literature, 9 clinical signs are associated with SD/THE [2-15]. Three are constant: intractable diarrhea, facial dysmorphism and hair abnormality. Two are very frequent (more than 90\%): IUGR and immunodeficiency; 2 are frequent: skin abnormalities and liver disease and 2 are rare: congenital cardiac defects and platelet anomaly.

The following description is based on the 44 reported cases [2-15] and data from 4 cases referred to our laboratory for genetic exploration. For each sign, the number of positives cases out of the total number of patients is indicated between brackets.

Intractable diarrhea (48/48): All the children presented intractable diarrhea of infancy defined as a chronic diarrhea persistent despite an enteral rest. This disease was at first diagnosed among children hospitalised for feeding problems. The onset of diarrhea was variable, from the first day to 32 weeks of life. Most children had parenteral nutrition during the follow up. The pathology analysis of intestinal tract showed normal (7/44) or mild to severe villous atrophy with no specific alterations, especially no sign specific of tufting enteropathy or microvillus inclusion disease. Colitis (16/22) or gastritis has also been found. 
Hair abnormalities are one of the most consistent signs as all children presented abnormal hair (48/48). Hair was described most often as woolly, easily removable, unmanageable, brittle and scanty. When searched, trichorrhexis nodosa were frequently found (35/39).

Facial dysmorphism (47/47): Children presented wide forehead, broad nasal root, hypertelorism, and coarse features (Figure 1). The facial dysmorphism can become more evident with time.

Immune defect (39/44): this sign was the most difficult to appreciate as investigations were different from one case to another. Signs reported most frequently were a low immunoglobin level (24 patients), a defect in antibody production after vaccination (14), monoclonal hyper IgA (3), a low lymphocytes count (2). Some children needed an immunoglobulin supplementation (temporarily or for a long period), some were prone to frequent infections.

IUGR/SGA (31/46): Most children had a small birth weight for gestational age: out of 41 with recorded weight, 30 children were below the 10th percentile and 27 below the third percentile (Figure 2). Moreover, 19 children out of 45 were preterm, due to medical extraction for severe IUGR in several cases.

Liver disease (23/44): More than half of the children had a liver disease. Cirrhosis (18) and siderosis were the main signs. Rarely, patients presented an isolated hepatomegaly. One patient was described as having a hepatoblastoma .

Skin abnormalities (18/36): Half of the children with skin description presented abnormalities (café au lait spot, xerosis, rubbery skin).

Cardiac abnormalities (8/31): Several children presented cardiac abnormalities: aortic insufficiency (2 patients), peripheral pulmonary stenosis (one patient), tetralogy of Fallot (one patient), atrial septal defect or ventricular septal defect (4 patients), persistent arterial duct (1 patient).

Platelet: first described by Hartley et al., platelet morphology has not been investigated in all patients. Increased size of the platelet was found in 5 out of 21 patients and was temporary in some cases. Phenotypic abnormalities observed in transmission electron microscopy were not performed in studies other than that of Hartley et al.

Other signs (inguinal hernia, thymus atrophy, small kidneys, Perthe syndrome, glaucoma, hypothyroid, polycystic kidney) were described in only a few patients. The association with THE syndrome might be coincidental.

Finally a slight mental retardation is noted in more than half of the patients but this is not well documented.

Signs described in THE syndrome are summarised in Table 1 with corresponding mutations. Regarding the data currently available, no genotype/phenotype correlation can be made either with the causative gene (TTC37 or $S K I V 2 L)$ or the mutation's type. In the case of children bearing the same mutation, the phenotype severity can vary from one individual to another.

\section{Aetiology}

$\mathrm{SD} / \mathrm{THE}$ is an autosomal recessive disease caused by mutation in SKIV2L in $40 \%$ of the cases or TTC37 in $60 \%$ of the cases [2-4]. These genes encode proteins ortholog of the yeast Ski2p and Ski3p respectively. In the yeast, ski2p and ski3p form, with two copies of ski8p, the ski complex [16]; it is thus likely that $S K I V 2 L$ and TTC37 form along with WDR61, the human ortholog of Ski8p, the putative human SKI complex. The functional part of the complex is $S K I V 2 L$ which is an RNA helicase, TTC37 and WDR61 (containing respectively TPR and WDR repeats) being involved in proteinprotein interactions. In 2005, Zhu et al. showed that these 3 human proteins co-localized with the human PAF but their association within a functional complex remains to be formally demonstrated [17]. The precise function of the ski complex in human is unknown but the ortholog genes are conserved throughout evolution in all eukaryotes especially in yeast and fruit fly, two models which provide most of the current data [18]. The ski complex is the cofactor of the cytosolic exosome whose function is to decay aberrant mRNAs in the 3'-5' way. The targeted mRNAs are no go, no stop mRNA

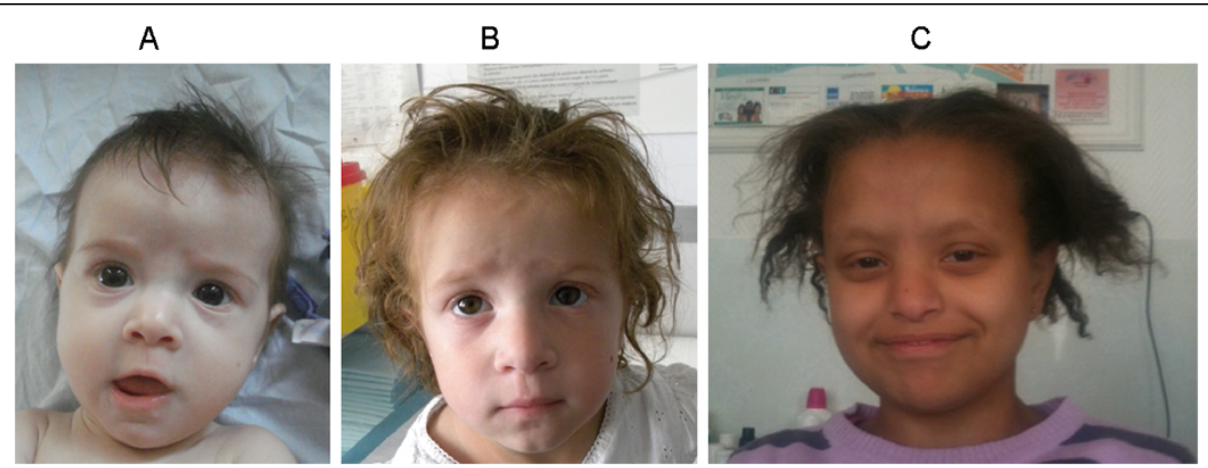

Figure 1 Clinical presentation of patients with mutations either in TTC37 (A at 8 month and B at 3 year) or SKIV2L (C). 

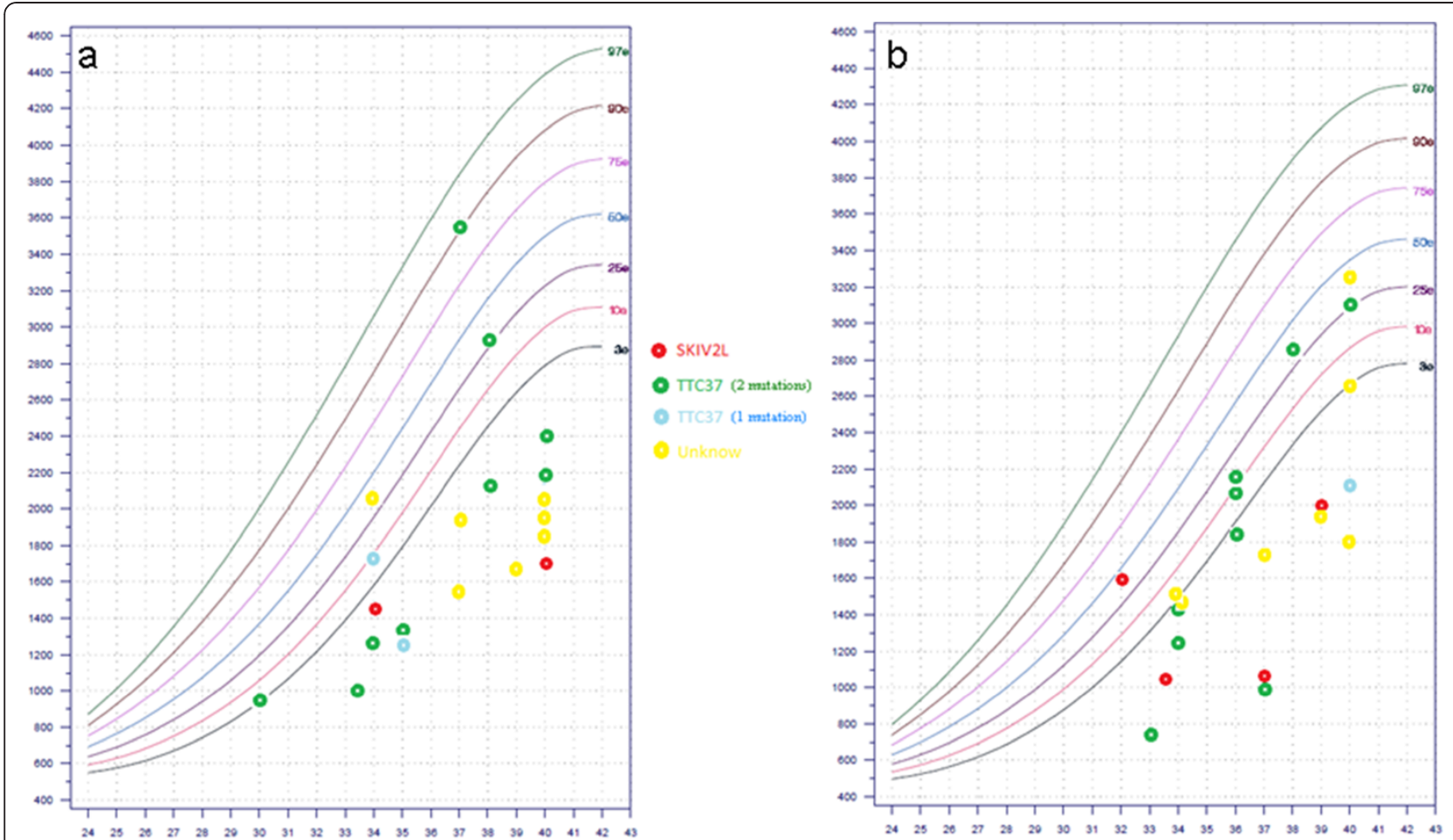

Figure 2 Birth weight for a) baby boys and b) baby girls with syndromic diarrhea/tricho-hepato-enteric syndrome according to molecular defects (Audipog Chart Growht www.audipog.net).

Table 1 Summary of clinical signs according to molecular defects

\begin{tabular}{|c|c|c|c|c|c|c|c|}
\hline & All $(n=48)$ & $\begin{array}{c}\text { Patients with } 2 \\
\text { mutations in } \\
T T C 37(\mathrm{n}=22)\end{array}$ & $\begin{array}{l}\text { Patient with } 1 \\
\text { mutation in } \\
T T C 37(\mathrm{n}=3)\end{array}$ & $\begin{array}{l}\text { Patient with } 2 \\
\text { mutations in } \\
\text { SKIV2L }(\mathrm{n}=7)\end{array}$ & $\begin{array}{l}\text { Patients not } \\
\text { tested }(n=16)\end{array}$ & $\begin{array}{l}\text { Patient from } \\
\text { Alqoed }(n=7)\end{array}$ & $\begin{array}{c}\text { Patient with } \\
\text { mutation p. } \\
\text { Trp936X }(n=5)\end{array}$ \\
\hline Consanguineous & $21 / 44$ & $14 / 21$ & $0 / 3$ & $4 / 7$ & $3 / 13$ & $6 / 7$ & $5 / 5$ \\
\hline Born before 37 we & $19 / 45$ & $11 / 21$ & $2 / 3$ & $3 / 6$ & $3 / 15$ & $1 / 7$ & $2 / 5$ \\
\hline Sex (F/M) & $27 / 20$ & $13 / 9$ & $1 / 2$ & $5 / 2$ & $8 / 7$ & $4 / 3$ & $3 / 2$ \\
\hline Birthweight mean & $\begin{array}{l}1825 \\
(780-3.580)\end{array}$ & $\begin{array}{c}1906 \\
(780-3580)\end{array}$ & $\begin{array}{l}1715 \\
(1345-2100)\end{array}$ & $\begin{array}{l}1473 \\
(1010-2000)\end{array}$ & $\begin{array}{l}1896 \\
(1410-3250)\end{array}$ & $2.61(1.6-3.9)$ & $\begin{array}{c}1986 \\
(1375-2400)\end{array}$ \\
\hline Intractable diarrhea & $48 / 48$ & $22 / 22$ & $3 / 3$ & $7 / 7$ & $16 / 16$ & $7 / 7$ & $5 / 5$ \\
\hline $\begin{array}{l}\text { Onset of diarrhoea } \\
\text { (weeks) means }\end{array}$ & $5.25(1-32)$ & $6.8(1-32)$ & 4 & $3.7(1-4)$ & $4.9(1-24)$ & $2(1-5.7)$ & \\
\hline Facial dysmorphy & $47 / 47$ & $22 / 22$ & $3 / 3$ & $6 / 6$ & $16 / 16$ & $6 / 7$ & $5 / 5$ \\
\hline Hair abnormalities & $48 / 48$ & $22 / 22$ & $3 / 3$ & $7 / 7$ & $16 / 16$ & $6 / 7$ & $5 / 5$ \\
\hline Trichorhexis nodosa & $35 / 39$ & $18 / 19$ & $2 / 3$ & $6 / 6$ & $9 / 11$ & $2 / 5$ & $4 / 4$ \\
\hline Immune deficiency & $39 / 44$ & $19 / 20$ & $3 / 3$ & $4 / 7$ & $13 / 14$ & $0 / 7$ & $4 / 5$ \\
\hline IUGR/SGA & $31 / 46$ & $12 / 21$ & $2 / 3$ & $5 / 7$ & $12 / 15$ & $5 / 7$ & $5 / 5$ \\
\hline Liver disease & $23 / 44$ & $11 / 19$ & $0 / 3$ & $3 / 6$ & $9 / 16$ & $2 / 7$ & $2 / 3$ \\
\hline Skin abnormalities & $18 / 36$ & 9/19 & $0 / 2$ & $3 / 4$ & $6 / 11$ & $7 / 7$ & $2 / 5$ \\
\hline Platelet abnormalities & $5 / 21$ & $5 / 17$ & $0 / 2$ & $0 / 2$ & & & $2 / 3$ \\
\hline Cardiac abnormalities & $8 / 31$ & $5 / 18$ & $1 / 2$ & $1 / 3$ & $1 / 8$ & & $2 / 5$ \\
\hline Outcome (died/alive) & $18 / 30$ & $5 / 17$ & $0 / 3$ & $2 / 5$ & $11 / 5$ & & $3 / 2$ \\
\hline
\end{tabular}


and viral RNA. The ski complex is essential to this function but the absence of a functional ski complex is not lethal probably because of the existence of the other mRNA decay pathway in the sense 5'-3, which is mediated by XRN1.

Most mutations are private mutations and are distributed in all exons without hot spot either in TTC37 or in SKIV2L. For TTC37, among 25 mutations found, 6 are missense, 5 are stop mutations, 5 are frame shift mutations due to deletion or insertion within the coding region and 9 are mutations in splice sites ( 3 of which cause a frame shift, 1 a deletion in the protein, 1 both a deletion and an insertion, and 4 have unknown effects on the protein). Trp936* is one of the rare recurrent mutations and has been found in 4 families among 25, all originating from India or Pakistan. For SKIV2L, among 9 mutations explored in 7 individuals from 7 families, 5 are deletions or insertion leading to frame shift, 3 are stop mutations and 1 a missense. There is no recurrent mutation. Table 2 summarizes currently published mutations.

\section{Diagnosis and diagnostic methods}

The association of intractable diarrhea of infancy, i.e. chronic diarrhea persisting despite enteral rest, with woolly hair and dysmorphism is highly suggestive of SD/THE. The

Table 2 Summary of mutations identified in TTC37 and SKIV2L

\begin{tabular}{|c|c|c|c|c|c|c|c|c|}
\hline Gene & $\begin{array}{c}\text { Type of } \\
\text { mutation }\end{array}$ & $\begin{array}{c}\text { Mutation } \\
\text { (Transcript) }\end{array}$ & Mutation (Protein) & Exon & $\begin{array}{c}\text { Number of } \\
\text { families }\end{array}$ & $\begin{array}{c}\text { Number } \\
\text { of affected } \\
\text { individuals }\end{array}$ & $\begin{array}{c}\text { References } \\
\text { for mutation } \\
\text { description }\end{array}$ & $\begin{array}{l}\text { References } \\
\text { for clinical } \\
\text { description }\end{array}$ \\
\hline \multirow[t]{25}{*}{$\overline{T T C 37}$} & Deletion & c.287_291del & p.(Leu96Trpfs*11) & 6 & 1 & 2 & {$[3]$} & [15] patient 22 \\
\hline & Stop & C. $439 \mathrm{C}>\mathrm{T}$ & p. $\left(\mathrm{G} \ln 147^{*}\right)$ & 8 & 1 & 1 & [2] & [2] patient 10 \\
\hline & Missense & c. $751 G>A$ & p.(Phe215GluFs*14) & 10 & 1 & 1 & {$[2]$} & [2] patient 7 \\
\hline & Deletion & c.811del & p.(Ser271Valfs*8) & 11 & 1 & 1 & Personal Data & \\
\hline & Deletion & c.1168del & p.(Val390Phefs*30) & 14 & 1 & 1 & [3] & \\
\hline & Deletion & c.1300_1301del & p.(Lys434Glyfs*14) & 15 & 1 & 1 & {$[2]$} & [2] patient 9 \\
\hline & Duplication & c.1305dup & p.(Tyr436Leufs*13) & 15 & 1 & 1 & Personal Data & \\
\hline & Splice site & c.1632+1del & p.(Glu545Phefs*40) & 17 & 1 & 1 & [2] patient 5 & [2] \\
\hline & Splice site & c.1453-1G >C & ND & 17 & 1 & 1 & Personal Data & \\
\hline & Stop & c. $1708 \mathrm{C}>\mathrm{T}$ & p.(Arg570*) & 18 & 1 & 1 & Personal Data & \\
\hline & Stop & c. $2251 C>T$ & p. $\left(G \ln 751^{*}\right)$ & 21 & 1 & 1 & [2] & [2] patient 10 \\
\hline & Splice site & c. $2515+1 G>C$ & p.(Cys813ValfsX56) & 23 & 1 & 1 & [3] & \\
\hline & Splice site & c.2578-7_2578-3del & p.(Asn860_878GluDel) & 25 & 1 & 1 & [3] & [1] patient 1 \\
\hline & Splice site & c. $2779-2 A>G$ & p.(Glu974Glyfs*19) & 28 & 2 & 2 & [2] & [2] patients 4 and 6 \\
\hline & Stop & c. $2808 \mathrm{G}>\mathrm{A}$ & p.(Trp936*) & 28 & 4 & 5 & [2] & [2] patients $1,2,8,12$, \\
\hline & Splice site & c.2921-2G > A & ND & 29 & 1 & 1 & {$[14]$} & \\
\hline & Splice site & c.3015-1G > A & ND & 30 & 1 & 1 & [3] & \\
\hline & Splice site & c. $3564-2 A>G$ & ND & 31 & 1 & 1 & [3] & \\
\hline & Missense & c. $3230 \mathrm{C}>\mathrm{A}$ & p.(Ala1077Asp) & 32 & 1 & 1 & [3] & [15] patient 18 \\
\hline & Missense & c. $3808 C>$ G & p.(Pro1270Ala) & 37 & 1 & 1 & [3] & \\
\hline & Missense & c. $3847 \mathrm{G}>\mathrm{A}$ & p.(Asp1283Asn) & 37 & 2 & 2 & [2] & [2] patients 3 and 11 \\
\hline & Stop & c. $3960 C>A$ & p. $($ Tyr1320*) & 38 & 1 & 1 & [3] & [1] patient 2 \\
\hline & Missense & c. $4454 \mathrm{~T}>\mathrm{G}$ & p.(Leu1485Arg) & 41 & 1 & 1 & [3] & \\
\hline & Missense & c. $4514 \mathrm{~T}>\mathrm{C}$ & p.(Leu1505Ser) & 42 & 2 & 2 & [2] & [2] patient 9 \\
\hline & Splice site & c. $4620+1 G>C$ & p.(Trp1524_1564Dellns61) & 42 & 1 & 1 & [3] & [1] patient 1 \\
\hline \multirow[t]{9}{*}{ SKIV2L } & Stop & $c .848 \mathrm{G}>\mathrm{A}$ & p.(Trp283*) & 9 & 1 & 1 & [4] & \\
\hline & Missense & c. $1022 T>G$ & p.(Val341Gly) & 10 & 1 & 1 & [4] & \\
\hline & Deletion & c.1434del & p.(Ser479Alafs*3) & 14 & 1 & 1 & [4] & [15] patient 25 \\
\hline & Insertion & c.1635_1636insA, & p.(Gly546Argfs*35) & 15 & 1 & 1 & [4] & [15] patient 21 \\
\hline & Stop & $c .2266 C>T$ & p. $\left(\operatorname{Arg} 756^{*}\right)$ & 19 & 1 & 1 & [4] & [15] patient 23 \\
\hline & Stop & c. $2442 \mathrm{G}>\mathrm{A}$ & p.(Trp814*) & 20 & 1 & 1 & {$[4]$} & [15] patient 23 \\
\hline & Deletion & c.2572del & p.(Val858*) & 21 & 1 & 1 & [4] & \\
\hline & Deletion & c.2662_2663del & p.(Arg888Glyfs*12) & 22 & 1 & 1 & {$[4]$} & \\
\hline & Deletion & c.3561_3581del & p.(Ser1189_Leu1195del) & 28 & 1 & 1 & Personal Data & \\
\hline
\end{tabular}


analysis of an intestinal biopsy is indicated to rule out other forms of intractable diarrhea caused by enterocyte abnormalities. The diagnosis is confirmed by the sequencing of TTC37 and SKIV $2 L$.

\section{Differential diagnosis}

SD/THE are mostly diagnosed by Hepato-gastro-intestinal pediatricians because the intractable diarrhea or the liver disease are the foremost signs. The main differential diagnoses are other causes of chronic diarrhea. Most of the non-genetic causes (infections and allergies) can be ruled out by explorations and clinical observation as they are resolved with adequate treatment. Among intractable diarrhea of infancy, only the syndromic tufting entheropathy also presents hair abnormalities [19], but it presents also specific pathologic abnormalities and can easily be differentiated by histological investigations. Children suffering from severe malnutrition can have hair abnormalities due to copper or iron deficiency but these features resolve with renutrition. In rare cases, neurofibromatosis has been evocated because of numerous café au lait spots.

\section{Genetic counseling}

$\mathrm{SD} / \mathrm{THE}$ is an autosomal recessive disorder. Considering the severity of the disease, an antenatal diagnosis could be offered to the parents of an affected child once the molecular defect is characterized.

\section{Management including treatment}

The management concerns the three life-threatening signs: intractable diarrhea leading to failure to thrive, immune abnormalities and liver disease. Intractable diarrhea often needs a parenteral nutrition to achieve nutrition and growth, during a variable period of time ranging from a few months to several years. In some cases, the association of enteral with parenteral nutrition can be indicated. For reasons of immune disorders, immunoglobulin supplementation is sometimes necessary and the antibody production after vaccination should be monitored. Finally, some children can present a severe liver disease independent of parenteral nutrition $[2,6,12]$ which could be worsened by the parenteral nutrition. In case of severe liver disease, the only therapeutic option is liver graft.

\section{Prognosis}

Even if the prognosis seems to have improved with years, there is still a high mortality rate (3/12 in Hartley et al. 2/12 for Fabre et al. and personal data). The main complications are liver disease and infections. Some patients are weaned off parenteral nutrition [2,13] but others remain under parenteral dependence for more than 10 years. Most of the children achieve a small final stature and half present a slight mental retardation.

\section{Unresolved questions}

The discovery of the molecular basis of SD/THE opens the perspective to better understand the disease and indicates that it must be considered as a mRNAs quality control disease even though the link between mutations in SKIV2L or TTC37 and dysfunction of the Ski complex remains to be formally demonstrated. Further investigations will allow us to understand how the alteration of a basic function such as RNA decay leads to these specific signs. There are probably several ways and environmental interactions which have to be investigated and a part of the pathology could be caused by misregulation of non coding RNAs. The possibility of the existence of milder forms, especially regarding gastrointestinal signs, has to be considered. In 2008, Al Qoer et al. described a cohort of children with mild diarrhea, hair and skin abnormalities who may possibly present an authentic SD/THE [20].

WDR61, the third component of the SKI complex, would have been a candidate gene for SD/THE in patients with no mutation in TTC37 or SKIV2L, but it supports other functions in meiosis and in the PAF complex making its involvement improbable [21].

\section{Conclusion}

$\mathrm{SD} / \mathrm{THE}$ is the first mendelian disease linked to a cytoplasmic exosome anomaly. With at least 2 genes involved, it is a genetically heterogeneous disease which should be evocated in cases of intractable diarrhea with hair abnormalities and confirmed by molecular diagnosis. Although improvements have been made recently regarding molecular basis and diagnosis, the prognosis remains severe.

\section{Competing interests}

The author declares no competing interests.

\section{Authors' contributions}

$A F$ and $C B$ take responsibility for the review and have been involved in drafting the manuscript and revising it critically; AF, CMV and OG conducted clinical investigations, collected clinical data and revised the manuscript. All authors have given final approval of the version to be published.

\section{Consent}

Written informed consent was obtained from the patient's parent for publication of this report and any accompanying images.

\section{Acknowledgments \\ This work was financially supported by the Assistance Publique-Hôpitaux deMarseille (AORC 2010). A.F. is supported by a scholarship from the Fondation Santé, Sport et Développement Durable de I'Université d'Aix- Marseille and from a grant of the Association pour le développement des recherches biologiques et médicales (ADEREM).}

\section{Author details}

'UMR_S 910, Inserm-Faculté de Médecine, Aix-Marseille Université, 13385, Marseille, France. ${ }^{2}$ AP-HM, Service de Pédiatrie Multidisciplinaire, Hôpital d'Enfants de la Timone, 13385, Marseille, France. ${ }^{3}$ AP-HP, Service de Gastroentérologie, Hôpital Robert Debré, 75019, Paris, France. ${ }^{4}$ Pediatric Gastroenterology-Hepatology and Nutrition, Reference Center for Rare Digestive Disease, Hôpital Necker-Enfants Malades/AP-HP, 75743, Paris, 
France. ${ }^{5} \mathrm{AP}-\mathrm{HM}$, Laboratoire de Génétique Moléculaire, Hôpital d'Enfants de la Timone, 13385, Marseille, France.

Received: 1 June 2012 Accepted: 18 December 2012 Published: 9 January 2013

\section{References}

1. Fabre A, André N, Breton A, Broué P, Badens C, Roquelaure B: Intractable diarrhea with "phenotypic anomalies" and tricho-hepato-enteric syndrome: two names for the same disorder. Am J Med Genet A 2007, 143:584-586.

2. Hartley JL, Zachos NC, Dawood B, Donowitz M, Forman J, Pollitt RJ, Morgan NV, Tee L, Gissen P, Kahr WH, Knisely AS, Watson S, Chitayat D, Booth IW, Protheroe S, Murphy S, de Vries E, Kelly DA, Maher ER: Mutations in TTC37 cause trichohepatoenteric syndrome (phenotypic diarrhea of infancy). Gastroenterology 2010, 138:2388-2398.

3. Fabre A, Martinez-Vinson C, Roquelaure B, Missirian C, André N, Breton A Lachaux A, Odul E, Colomb V, Lemale J, Cézard JP, Goulet O, Sarles J, Levy $\mathrm{N}$, Badens C: Novel mutations in TTC37 associated with tricho-hepatoenteric syndrome. Hum Mutat 2011, 32:277-281.

4. Fabre A, Charroux B, Martinez-Vinson C, Roquelaure B, Odul E, Sayar E, Smith H, Colomb V, Andre N, Hugot JP, Goulet O, Lacoste C, Sarles J, Royet J, Levy $\mathrm{N}$, Badens C: SKIV2L mutations cause syndromic diarrhea, or trichohepatoenteric syndrome. Am J Hum Genet 2012, 90:689-692.

5. Canani BR, Terrin G, Cardillo G, Tomaiuolo R, Castaldo G: Congenital diarrheal disorders: improved understanding of gene defects is leading to advances in intestinal physiology and clinical management. $J$ Pediatr Gastroenterol Nutr 2010, 50:360-366.

6. Stankler L, Lloyd D, Pollitt RJ, Gray ES, Thom H, Russell G: Unexplained diarrhoea and failure to thrive in 2 siblings with unusual facies and abnormal scalp hair shafts: a new syndrome. Arch Dis Child 1982, 57:212-216.

7. Girault D, Goulet O, Le Deist F, Brousse N, Colomb V, Césarini JP, de Potter S, Canioni D, Griscelli C, Fischer A, Ricour C: Intractable infant diarrhea associated with phenotypic abnormalities and immunodeficiency. J Pediatr, 125:36-42.

8. Verloes A, Lombet J, Lambert Y, Hubert AF, Deprez M, Fridman V, Gosseye S, Rigo J, Sokal E: Tricho-hepato-enteric syndrome: further delineation of a distinct syndrome with neonatal hemochromatosis phenotype, intractable diarrhea, and hair anomalies. Am J Med Genet 1997, 68:391-395.

9. De Vries E, Visser DM, van Dongen JJ, Jacobs $\mathrm{CJ}$, Hoekstra JH, van Tol MJ. Oligoclonalgammopathy in phenotypic diarrhea. J Pediatr Gastroenterol Nutr 2000, 30:349-350.

10. Landers MC, Schroeder TL: Intractable diarrhea of infancy with facial dysmorphism, trichorrhexisnodosa, and cirrhosis. Pediatr Dermatol 2003, 20:432-435.

11. Barabino AV, Torrente F, Castellano E, Erba D, Calvi A, Gandullia P: "Syndromic diarrhea" may have better outcome than previously reported. J Pediatr 2004, 144:553-554.

12. Dweikat I, Sultan M, Maraqa N, Hindi T, Abu-Rmeileh S, Abu-Libdeh B: Tricho-hepato-enteric syndrome: a case of hemochromatosis with intractable diarrhea, dysmorphic features, and hair abnormality. Am J Med Genet A 2007, 143:581-583.

13. Egritas $\mathrm{O}$, Dalgic $\mathrm{B}$, Onder M: Tricho-hepato-enteric syndrome presenting with mild colitis. Eur J Pediatr 2009, 168:933-935.

14. Bozzetti V, Bovo G, Vanzati A, Roggero P, Tagliabue P: A new genetic mutation in a patient with syndromic diarrhea and hepatoblastoma. J Pediatr Gastroenterol Nutr; http://journals.Iww.com/jpgn/Citation/publishahead/ A_New_Genetic_Mutation_in_a_Patient_with_Syndromic.99023.aspx.

15. Goulet O, Vinson C, Roquelaure B, Brousse N, Bodemer C, Cézard JP: Syndromic (phenotypic) diarrhea in early infancy. Orphanet J Rare Dis 2008, 3:6.

16. Synowsky SA, Heck AJ: The yeast Ski complex is a hetero-tetramer. Protein Sci 2008, 17:119-125.

17. Zhu B, Mandal SS, Pham AD, Zheng Y, Erdjument-Bromage H, Batra SK Tempst P, Reinberg D: The human PAF complex coordinates transcription with events downstream of RNA synthesis. Genes Dev 2005, 19:1668-1673.

18. Schaeffer D, Clark A, Klauer AA, Tsanova B, van Hoof A: Functions of the cytoplasmic exosome. Adv Exp Med Biol 2011, 7:79-90.
19. Bird LM, Sivagnanam M, Taylor S, Newbury RO: A new syndrome of tufting enteropathy and choanal atresia, with ophthalmologic, hematologic and hair abnormalities. Clin Dysmorphol 2007, 16:211-221.

20. Al Qoaer K, Al Mehaidib A, Shabib S, Banemai M: Chronic diarrhea and skin hyperpigmentation: a new association. Saudi J Gastroenterol 2008, 14:187-191.

21. Dorcey E, Rodriquez-Villalon A, Salinas P, Santuari L, Pradervand S, Harshman K, Hardtke CS: Context-dependent dual role of SKI8 homologs in mRNA synthesis and turnover. PLoS Genet 2012, 8(4).

doi:10.1186/1750-1172-8-5

Cite this article as: Fabre et al:: Syndromic diarrhea/Tricho-hepatoenteric syndrome. Orphanet Journal of Rare Diseases 2013 8:5.

\section{Submit your next manuscript to BioMed Central and take full advantage of:}

- Convenient online submission

- Thorough peer review

- No space constraints or color figure charges

- Immediate publication on acceptance

- Inclusion in PubMed, CAS, Scopus and Google Scholar

- Research which is freely available for redistribution

Submit your manuscript at www.biomedcentral.com/submit

C Biomed Central 